\title{
Novel feeds in organic dairy chains
}

\author{
MARKETTA RINNE ${ }^{1}$, CATALIN DRAGOMIR ${ }^{2}$, KAISA KUOPPALA ${ }^{1}$, JO SMITH $^{3}$ AND DAVID YÁÑEZ-RUIZ ${ }^{4}$
}

Key words: agroforestry, by-products, digestibility, feed value

\begin{abstract}
The objective of the current work was to collect information on various novel and underutilized feeds and thus increase the awareness of various novel feeding solutions to support organic and low-input dairy production. A sample set of various feeds such as food and winery industry by-products, forestry materials and novel legumes was collected from Spain, Romania, UK and Finland and analysed for chemical composition and digestibility. The range of potential novel and underutilized feeds is large. The results can be used to aid in exploiting the potential of different feed resources and in ration formulation, and demonstrate potential to widen the basis of feed supply on organic and low input dairy farms. The economic effects of use of novel feeds is greatly dependent on the pricing of the feeds but may in many cases be expected to be positive.
\end{abstract}

\section{Introduction}

Innovative use of novel and underutilized feed resources has the potential to improve the efficiency of the "green economy". Increasing the supply of new feed ingredients acceptable in organic production would in many cases allow for an increase in the supply of organic milk, and farm flexibility in terms of feeding strategies. Increasing organic food production of e.g. vegetable and oil based products and wine also provides the opportunity to produce organic by-products suitable for animal feeding. Further, on-farm production of novel or underutilized forages may provide new opportunities for the feed supply. Agroforestry may be one opportunity as well as introducing new forage crops from other regions or rediscovering the use of neglected crops.

The objective of the current work was to collect information on various feeds and thus increase the awareness of various novel feeding solutions, and it builds on a previously conducted literature review on the same topic (Rinne et al. 2012). The research leading to these results has received funding from the European Community's Seventh Framework Programme (FP7/ 2007-2013) under the grant agreement $n^{\circ}$ FP7-266367 (SOLID, for more information, see: www.solidairy.eu).

\section{Material and methods}

A sample set of various novel and underutilized feeds was collected from Spain, Romania, UK and Finland in order to evaluate their potential as feed ingredients for organic and low-input dairy production. Their chemical composition was analysed using standard procedures in the participating laboratories following guidelines of AOAC. The results of a selected sample set are presented in Table 1.

\section{Results and Discussion}

The analyses of the composition of the by-products obtained from the tomato, olive oil and pomegranate industries revealed a high range of variation, with lower protein and higher fibre content for olive by-products than for tomato and pomegranate ones. Ensiling both olive oil and tomato by-products is feasible and provides a cheap way of preserving material that is high in moisture. The dry matter (DM) digestibility of the ensiled material ranged from $590 \mathrm{~g} / \mathrm{kg}$ DM for olive pulp and leaves silage to $751 \mathrm{~g} / \mathrm{kg}$ DM for tomato silage. Based on the composition observed in this study, it is suggested that olive by-products could replace medium quality roughage, while tomato derived feeds may partially replace cereal grain in the ration of ruminants, which would contribute to reducing the feeding associated costs on the farm.

Wineries generate substantial quantities of wastes that, according to environment-specific rules, have to be properly disposed. Their use as a feed resource for ruminants is a convenient option, especially in low-input production systems. While grape marc crude protein level is similar to that of cereals $(115 \mathrm{~g} / \mathrm{kg} \mathrm{DM})$, there are digestibility concerns, which are currently investigated. As part of the grape marc is processed for oil extraction, some quantities of grape seed meals are also available. When wine is produced in an organic

\footnotetext{
${ }^{1}$ MTT Agrifood Research Finland, www.mtt.fi, eMail: marketta.rinne@mtt.fi

${ }^{2}$ National Institute for Research-Development in Animal Nutrition and Biology, Romania

${ }^{3}$ Organic Research Centre, UK

${ }^{4}$ Estacion Experimental del Zaidin,CSIC, Spain
} 
system, the wastes are also eligible for organic milk production, provided appropriate processing technologies (e.g. mechanical extraction of oil) are used.

Another feed source is the cakes from the cold-extraction of oils from various oilseed plants, such as Camelina, safflower etc. The potential use of these cakes within organic dairy production system is favoured by several facts: they are low-input, easy to manage cultivars; there is a practice of contracting the harvest with oil-extracting companies and getting back the cakes and, in many cases, the oil processing is mechanical (suitable for organic systems), and they have a high nutritive value. For example, the analyses of Camelina meal revealed a high content of crude protein (379 $\mathrm{g} / \mathrm{kg} \mathrm{DM})$ and a relatively high content of residual oil (157 $\mathrm{g} / \mathrm{kg} \mathrm{DM})$. Such feed is a useful component in dairy rations.

Agroforestry, the integration of trees and agriculture, is valued as a multifunctional land use approach that balances the production of commodities (food, feed, fuel, fibre, etc.) with non-commodity outputs such as environmental protection and cultural and landscape amenities (IAASTD, 2008). Browse from trees and shrubs plays an important role in feeding ruminants in many parts of the world, particularly in the tropics, and there has been considerable research into the nutritional potential and limitations of many tropical fodder species, but comparatively little is known about the potential of temperate browse species. Although the feed values were low, willow may have a role in multifunctional systems, where it can provide additional values in grazing situations such as microclimate benefits for livestock and a range of ecosystem services.

Wood-derived hemicellulose products from a pressurized hot water extraction represent a novel industrial byproduct. The material has a reasonable energy value for ruminants, but currently there is no supply for feed markets.

Novelty is a very subjective term. A good example of this is maize silage, which is a very common feed plant in Central and Southern Europe, but novel in Northern Europe. The analyses revealed that when grown under the Northern climatic conditions, the feeding value of it is very different from what would be expected, i.e. the DM and starch concentrations of it were low indicating too early maturity of the plants at harvest, and relatively low value in dairy rations.

Some feed plants may be known since ancient times, but have recently been used only rarely. In new situations, they may have potential. The use of legumes is of particular interest for organic farms. Faba bean and pea whole crops as pure stands or in combinations with cereals (wheat or oats) resulted in reasonable feed values even when grown in Northern Finland.

Based on the current sample set, the range of potential novel and underutilized feeds is large. The current results can be used to aid in exploiting the potential of different feed resources and in ration formulation.

\section{Conclusions}

Novel and underutilized feeds provide opportunities to supplement diets of organic and low input dairy farms in order to improve the nutrient supply and subsequently milk production of the animals. Improved supply of feeds may be particularly favourable in situations when the basal feed supply is reduced due to e.g. weather conditions. The economic effects of use of novel feeds is greatly dependent on the pricing of the feeds but may in many cases be expected to be positive. Widening the type of on-farm produced feeds may also have beneficial effects beyond simply feed supply such for crop rotation, self-medication, microclimate or other ecosystem services. In some cases, use of novel feeds may also include risks e.g. to animal health (antinutritional factors), milk quality, or consumer acceptability, and these factors must be kept in mind when innovative solutions are developed. 
Table 1. Characterization of a selected set of "novel" feed samples.

\begin{tabular}{|c|c|c|c|c|c|c|c|c|c|c|}
\hline & \multirow{2}{*}{ Origin } & \multirow{2}{*}{$\mathrm{n}$} & \multirow{2}{*}{$\begin{array}{l}\text { Dry } \\
\text { matter, } \\
\text { g/kg }\end{array}$} & \multicolumn{6}{|c|}{ In dry matter, g/kg } & \multirow{2}{*}{$\begin{array}{l}\text { Digesti- } \\
\text { bility* }\end{array}$} \\
\hline & & & & Ash & $\mathrm{CP}$ & Starch & NDF & ADF & Lignin & \\
\hline Tomato fruit waste & Spain & 11 & 615 & 101 & 103 & & 191 & 139 & 49 & 910 \\
\hline Tomato silage & Spain & 3 & 521 & 112 & 119 & & 516 & 234 & 121 & 751 \\
\hline Olive pulp & Spain & 18 & 676 & 111 & 99 & & 632 & 430 & 236 & 512 \\
\hline Olive leaves & Spain & 16 & 515 & 119 & 74 & & 418 & 282 & 167 & 544 \\
\hline $\begin{array}{l}\text { Olive pulp and } \\
\text { leaves silage }\end{array}$ & Spain & 3 & 575 & 127 & 88 & & 390 & 240 & 145 & 590 \\
\hline Pomegranate pulp & Spain & 8 & 671 & 52 & 121 & & 121 & 89 & 21 & 760 \\
\hline Grape marc & Romania & 6 & 876 & 63 & 115 & & 657 & 566 & & \\
\hline Camelina meal & Romania & 4 & 907 & 62 & 379 & & 164 & 130 & & \\
\hline Willow silage & UK & 12 & 278 & 80 & 195 & & 389 & 278 & 74 & 506 \\
\hline Dried willow & UK & 16 & 356 & 68 & 129 & & 529 & 376 & 155 & 437 \\
\hline $\begin{array}{l}\text { Wood derived } \\
\text { hemicell. } \\
\text { extract }\end{array}$ & Finland & 7 & & 12 & 5 & & & & & 623 \\
\hline Maize silage & Finland & 9 & 162 & 51 & 116 & 92 & 507 & & & 787 \\
\hline $\begin{array}{l}\text { Faba bean whole } \\
\text { crop }\end{array}$ & Finland & 9 & & 54 & 162 & 82 & 414 & & & 766 \\
\hline $\begin{array}{c}\text { Faba bean+cereal } \\
\text { whole crop }\end{array}$ & Finland & 12 & 199 & 66 & 120 & 101 & 512 & & & 659 \\
\hline Pea whole crop & Finland & 12 & & 60 & 167 & 67 & 404 & & & 767 \\
\hline $\begin{array}{l}\text { Pea+cereal whole } \\
\text { crop }\end{array}$ & Finland & 12 & 185 & 77 & 142 & 56 & 520 & & & 661 \\
\hline
\end{tabular}

$\mathrm{CP}=$ Crude protein $\quad$ NDF $=$ Neutral detergent fibre $\quad$ ADF $=$ Acid detergent fibre

*In vitro pepsin cellulase solubility (Huhtanen et al. 2006) for Finnish and UK samples, Ankom in vitro digestibly procedure (Martín-García et al. 2004) for Spanish samples

\section{References}

Huhtanen, P., Nousiainen, J. \& Rinne, M. 2006. Recent developments in forage evaluation with special reference to practical applications. Agricultural and Food Science 15: 293-323.

IAASTD, 2008. Executive summary of the synthesis report. International Assessment of Agricultural Knowledge, Science and Technology for Development.

Martíın-Garcíla, A.I., Yáñez Ruiz, D.R. Moumen, A \& E. Molina Alcaide. 2004. Effect of polyethylene-glycol on the chemical composition and nutrient availability of olive (Olea europaea var. europaea) by-products. Animal Feed Science and Technology. 114: 159-177.

Rinne, M., Dragomir, C., Kuoppala, K., Marley, C., Smith., J. \& Yáñez -Ruiz, D. 2012. Novel and underutilized feed resources - potential for use in organic and low input dairy production. The 2nd IFOAM Animal Husbandry Conference, September 12-14, 2012, Hamburg, Germany. vTi Agriculture and Forestry Research, Special issue 362. p. 417-420. 
RINNE M, et al. 